\title{
Perks and perils of adult learners in Communication English learning at English language centers in Vietnam
}

\author{
Truong Minh Hoa \\ College of Foreign Economics and Relations, 81 Tran Binh Trong Street, Ho Chi Minh City, Vietnam \\ tmh.camranh1991@gmail.com
}

\section{ARTICLE INFO}

Article history

Received 20 October 2020

Revised 03 December 2020

Accepted 30 December 202

Keywords

perks

perils

adult learners

Communication English

Vietnam

\begin{abstract}
The teaching and learning of Communication English for adult learners is unlike that for children. Understanding of the differences between adult learners' and young learners' traits is considered a must for all English teachers so as to provide appropriate teaching methods and materials for adult learners in Communication English learning. Thus, this mixed-methods survey was conducted to investigate adult learners' perks and perils in Communication English learning and suggested solutions for their better communicative performance. The sample of this study consisted of 148 adult learners from the five selected language centers in Ho Chi Minh City, Vietnam. Data were collected from questionnaire copies. The findings revealed that the adult learners had some perks including strong motivation, clear learning goal, good learner autonomy and able technology use for learning, or positive attitudes towards the existing teachers' quality. Besides, some perils among these adult learners were sought, including low self-confidence, short time investment, and limited speaking practice environment. At last, they expected their teachers to make the lessons more interesting and realistic, and hoped their language centers to invite native language teachers.
\end{abstract}

This is an open access article under the CC-BY-SA license.

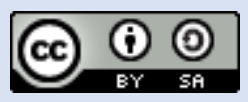

How to Cite: Truong, M. H. (2021). Perks and perils of adult learners in communication English learning at English language centers in Vietnam. English Language Teaching Educational Journal, 4(3), 213-224.

\section{Introduction}

Being competent in oral communication is a growing desire of all English learners. And speaking is a fundamental skill that learners need to master in order to communicate effectively. Indeed, Ur (2013) states that of all the four language skills, speaking seems intuitively the most important one as the ability to speak skillfully provides for the speakers with a favorable condition to establish and maintain relationships, to negotiate, and to influence others. In the same fashion, Nunan (1991) views that to most people, success is measured in terms of the ability to carry out a good conversation in the target language. This increasing demand for good communicative skill in a globalized society activates English speaking learning around the world (Enever, 2018), including in Vietnam.

Currently, Vietnam has been the member of many international organizations like Association of South-East Asia Nations (ASEAN); World Trade Organization (WTO); or Asia Pacific Economics Conference (APEC). In these communities, Vietnamese people who are not born as English speakers have learned English language in order to be able to communicate with other people. In other words, English is used throughout these communities as lingua franca, "the common language used by people of different language backgrounds to communicate with each other" (Kirkpatrick, 2007). As a result, the English language has shifted from being a language that was primarily used to serve native speakers' intra-national and communal purposes to becoming an international medium in lingua franca communication (Kirkpatrick, 2007). In response to this change, Vietnamese people need to use English effectively to interact with others who come from different linguistic backgrounds. In order 
to do so, the language must be understood by both sides to make the communication successful. Thus, it is axiomatic that the utmost important goal of learning English is to be capable of communicating well in English; that is, the goal of language learning "is concerned with developing the ability to use language in communicative situations" (Larsen-Freeman, 2018). In reality, there have been more and more communication courses in Vietnam held to satisfy leaners' need of improving English speaking ability.

However, many Vietnamese learners still find it difficult to communicate fluently and confidently. This alarming predicament happens exactly to a large number of adult learners in Vietnam. After many years of being exposed to English in secondary and high schools, and even at tertiary level, many of them are still unable to perform a simple and short conversation in English (Pham, Than, \& Truong, 2020) due to a set of complicated factors such as highly pressured performance conditions and limited listening ability (Heriansyah, 2012; Nguyen \& Tran, 2015), low motivation and selfconfidence, and high anxiety (Juhana, 2012; Leong \& Ahmadi, 2017), immature topical and linguistic input (Mazouzi, 2013; Hosni, 2014), counter-productive ELT materials and curricular, and inflexible teacher roles (Dao, 2017; Yaseen, 2018). Especially, adult learners may feel embarrassed about being students against for the feeling of being old and away from schools for many years (Singleton \& Záborská, 2020).

Notwithstanding the perils of learning Communication English mentioned above, there are still perks among Vietnamese adult learners, "persons over the normal age of traditional schooling, who freely choose to get involved in a particular form of instruction, to serve a professional, social or personal need and interest" (Cozma, 2015), contributing to their success in English learning. First, as they are adults, they are goal-oriented and experienced, and have much greater cognitive and linguistic capabilities than young learners (Kuklewicz \& King, 2018). In specific, this group of learners are goaloriented and motivated since when they learn, they want to accomplish specific needs or demands such as to support their study, to be promoted in career, to make more friends or to be good language users (Merriam, 2017; Lavrysh \& Lytovchenko, 2019; Lytovchenko, Ogienko, Sbruieva \& Sotska, 2018). That is the reason why "adult learners have better study habits than the younger learners in that they engaged in deeper learning than do the younger learners" (Xolmurodova, 2021). Second, thanks to the technology advancement (e.g., ICT, Internet) and the widespread establishment of English centers across Viet Nam, Vietnamese adult learners can seek a convenient English learning environment with their self-paid tuition fee.

There are some problems among adults learning English as a second language (Madkur, 2018; Wu $\&$ Le, 2014). One noticeable problem, nevertheless, is that most of the adult learners attend to English classes empty-handed. It means that they just simply come to school to learn what they are taught without paying attention to both perks and perils they are possessing and facing. For adult learners, those aspects need considering carefully since they might directly affect the learning outcomes. It is witnessed that numerous adult learners who fail to communicate in English because of not being aware of the perks and perils of their learning process. Therefore, the present survey study was conducted to investigate two sides of adult learners when they are learning Communication English, then useful solutions for helping these adult learners improve their English communicative competence. To achieve this objective, the current paper aims to address the two following research questions:

1. What are the perks and perils of adult learners in Communication English learning?

2. What are the adult learners' suggested solutions to strengthen the perks and to overcome the perils in Communication English learning?

\section{Method}

\subsection{Research Locale and Participants}

The current study was carried out at the five selected language centers in Ho Chi Minh City, Vietnam. The most common trait of these five language centers was to provide learners with different Communication English courses, which were designed based on the adult learners' existing proficiency levels. The research participants were 148 adult learners from the selected five language centers, whose background information is presented in Table 1. 
Table 1. Research Participants' Profile

\begin{tabular}{llcc}
\hline & $\mathbf{N}=\mathbf{1 4 8}$ & Frequency $(\mathbf{F})$ & Percentage (5) \\
\hline \multirow{2}{*}{ Gender } & Male & 58 & 39.2 \\
& Female & 90 & 60.8 \\
\hline \multirow{4}{*}{ Age } & $18-22$ & 60 & 40.5 \\
(years old) & $23-28$ & 52 & 35.1 \\
& $29-35$ & 26 & 17.6 \\
& $36-45$ & 7 & 4.7 \\
& Above 45 & 3 & 2.0 \\
\hline \multirow{4}{*}{ Occupation } & Finance-Banking & 20 & 13.5 \\
& Tourism, Hotel & 30 & 20.3 \\
& Medicine & 4 & 2.7 \\
& Education & 23 & 15.5 \\
& Law & 26 & 17.6 \\
& Accounting & 22 & 14.9 \\
English learning experience & Human resource & 19 & 12.8 \\
(years) & Construction & 4 & 2.8 \\
& $1-3$ & 7 & 4.7 \\
& $4-7$ & 47 & 31.8 \\
& $8-10$ & 68 & 45.9 \\
& Above 10 & 26 & 17.6 \\
\hline
\end{tabular}

As shown in Table 1, of 148 participants, there were 58 males (39.2\%) and 90 females $(60.8 \%)$. Their ages ranged variously from 18 to 45 years old, but most of them were from 18-22 (40.5\%) and 23-28 (35.1\%). Regarding their occupations, these adult learners worked in different sectors of career like tourism, hotel (20.3\%), law (17.6\%), education (15.5\%), accounting (14.9\%), or finance-banking $(13.5 \%)$, or human resource $(12.8 \%)$, and so on. Furthermore, most of the respondents had learned English from 4 to 10 years; that is, 4-7 years (31.8\%), and 8-10 years (45.9\%).

\subsection{Research Design}

Overall, the present study was grounded by a survey design, which is "a procedure in which any researcher administers a survey to a sample [...] to describe the attitudes, opinions, behaviors, or characteristics of the sample" (Creswell, 2019). This survey was to examine 148 adult learners' perks and perils in Communication English learning and their own suggestions for better learning and teaching quality of Communication English.

\subsection{Research Instrument: Questionnaire}

\section{Rationale}

In this study, the researcher deliberately used a questionnaire, a written instrument by which the respondents can select the best option from among existing answers (Iwaniec, 2019), to garner data for the present study due to two salient reasons. Among many advantages of using questionnaires, some of them include practicality, economy, feasibility, time, efficiency, versatility, ease of construction, and data analysis (Curle \& Derakhshan, 2021; Patten, 2016). Furthermore, questionnaire is known to be one of the easiest methods to manage, especially with large numbers of subjects. Dörnyei \& Taguchi (2010) highlight that questionnaires are very popular and one of the most common methods of data collection in L2 research because they are easy to construct, extremely versatile, capable of gathering a large amount of information quickly in such a way that is readily processable. Besides, questionnaire tends to be more reliable as it encourages greater honesty from respondents and saves the researcher's and participants' time and effort.

\section{Description}

The questionnaire consisted of nine questions in total. These nine questions covered sub-themes of the adult learners' perks, perils, and suggested solutions for Communication English learning. The questionnaire was highly reliable and valid because the researcher constructed it in a highly-structured way, afterwards had experts to double-check its content, scales, layout of both English and Vietnamese versions, and finally conducted a pilot study. Below is the questionnaire's detail. 
Table 2. Description of Questionnaire

\begin{tabular}{|c|c|c|}
\hline Sub-themes & Questions & Options \\
\hline Main motive & $\begin{array}{l}\text { 1-What is your main motive of learning Communication } \\
\text { English? }\end{array}$ & 6 (=1 accepted $)$ \\
\hline Self-Study Time Investment & $\begin{array}{l}\text { 2-Do you invest time for self-study every day? If yes, how long } \\
\text { for each time of self-study? }\end{array}$ & 6 (=1 accepted) \\
\hline $\begin{array}{l}\text { Communication English Use } \\
\text { Outside Class }\end{array}$ & $\begin{array}{l}\text { 3-Do you use English for communicative needs? If yes, in } \\
\text { which cases? }\end{array}$ & 5 (>=1 accepted) \\
\hline $\begin{array}{l}\text { Hindrances of Communication } \\
\text { English Use }\end{array}$ & $\begin{array}{l}\text { 4-In cases of using English for communicative purposes, what } \\
\text { hindrances influence your speaking performance? }\end{array}$ & 5 ( $>=1$ accepted) \\
\hline $\begin{array}{l}\text { Overall Evaluation of } \\
\text { Communication English Class }\end{array}$ & $\begin{array}{l}\text { 5-How do you evaluate your Communication English class in } \\
\text { general? }\end{array}$ & 5 ( $>=1$ accepted $)$ \\
\hline Self-Evaluation of Language & 6-How do you evaluate the content of your Communication & 3 pairs \\
\hline Curriculum & English curriculum at your language center? & $\begin{array}{l}1 \text { pair: } 2(=1 \\
\text { accepted })\end{array}$ \\
\hline Perceived Possible Perks & $\begin{array}{l}\text { 7-What perks do you have when starting to learn } \\
\text { Communication English? }\end{array}$ & 9 (>=1 accepted) \\
\hline Perceived Existing Perils & $\begin{array}{l}\text { 8-What perils do you face when learning Communication } \\
\text { English? }\end{array}$ & 9 (>=1 accepted) \\
\hline Suggested Solutions & $\begin{array}{l}\text { 9-What are your suggestions to improve the quality of your } \\
\text { Communication English courses? }\end{array}$ & 5 (>=1 accepted) \\
\hline
\end{tabular}

\subsection{Data Collection and Analysis}

On the chosen dates, the questionnaire copies which had been translated into Vietnamese beforehand were delivered to 148 adult participants. On the receipt of questionnaires from the respondents, the researcher found that all 148 copies (100\%) were valid and accepted. Finally, the researcher employed Statistical Package for the Social Sciences (SPSS) version 20.0 to analyze the descriptive statistics of the collected questionnaires in terms of frequency $(\mathrm{F}, \mathrm{n})$ and percentage $(\mathrm{P}$, $\%)$. Frequency $(\mathrm{F}, \mathrm{n})$ is a sort of tool which counts the number of times people did the same things, while percentage $(\mathrm{P}, \%)$ is mostly integrated with frequencies to present a clear picture of a certain phenomenon.

\section{Finding and Discussion}

\subsection{Findings}

From Table 3, the adult learners attended the Communication English classes for different purposes. In details, more than one-third of the total sample (39.2\%) learnt Communication English to help them negotiate effectively with either customers or colleagues. Likewise, approximately onethird of the response community (33.8\%) explained that meeting the qualification requirement at the workplace or school was the primary motive for their attendance in Communication English courses. Besides, some learning motives were also found but only at low rates; that is, going to study abroad $(12.8 \%)$, seeking a new job conveniently $(8.1 \%)$, relaxing and entertaining $(4.7 \%)$, travelling $(1.4 \%)$.

Table 3. The adult learners' main motive of Communication English learning

\begin{tabular}{lll}
\hline \multicolumn{1}{c}{ Main Motive } & F (n) & P (\%) \\
\hline I learn Communication English to negotiate in English for work & 58 & 39.2 \\
I learn Communication English to seek a new job & 12 & 8.1 \\
I learn Communication English to meet the qualification requirement at workplace/ school & 50 & 33.8 \\
I learn Communication English to use it for traveling & 2 & 1.4 \\
I learn Communication English to entertain (e.g. watch films, listen to music) & 7 & 4.7 \\
I learn Communication English to use it for studying abroad & 19 & 12.8 \\
Total & 148 & 100.0 \\
\hline
\end{tabular}


Table 4. The adult learners' time investment for self-study

\begin{tabular}{lll}
\hline \multicolumn{1}{c}{ Self-Study Time Investment } & F (n) & P (\%) \\
\hline No time for self-study & 25 & 16.9 \\
Less than thirty minutes & 55 & 37.2 \\
From thirty minutes to one hour & 46 & 31.1 \\
From more than one hour to two hours & 20 & 13.5 \\
From more than two hours to three hours & 2 & 1.4 \\
More than three hours & 0 & 0.0 \\
Total & 148 & 100.0 \\
\hline
\end{tabular}

As observed from Table 4, by the highest frequency number, there were 55/148 informants (37.2\%) spending less than half an hour for each time of self-studying Communication English. By the second highest frequency number, nearly one-third of the total sample $(31.1 \%)$ invested only from thirty minutes to one hour for each time of self-study. It is indicated that the more the time investment for each time of self-learning Communication English increased, the fewer there were adult learners; for example, only $13.5 \%$ of the entire sample utilized from more than one hour to two hours for their selfstudy outside the class; more notably, only $1.4 \%$ of them used from more than two hours to three hours to practice or review Communication English lessons at home; surprisingly, no adult learners of this study invested more than three hours for their self-study outside the class. Especially, according to the revelation of 25 surveyed participants (16.9\%), they did not have time fund to invest for selfstudy outside the language center. In other words, these learners only acquired Communication English right at their language schools.

Table 5. The adult learners' use of English for communicative needs outside the class

\begin{tabular}{lll}
\hline Communication English Use Outside Class & F (n) & P (\%) \\
\hline I use English for work & 74 & 50.0 \\
I use English when participating English language clubs & 53 & 35.8 \\
I use English to communicate with my foreign friends & 30 & 20.3 \\
I use English for speaking practice with my friends & 116 & 78.4 \\
I do not have realistic environment for using English outside the class & 29 & 19.6 \\
\hline
\end{tabular}

As presented in Table 5, half of the total sample (50.0\%) utilized Communication English for work. It is referred that these adults used English as a means of negotiating with their colleagues or clients. Positively, $35.8 \%$ of the response community reported that they used Communication English when taking part in the language clubs. In other words, these students had positive learning attitudes for a better communicative ability. Interestingly, outside the Communication English class, one-fifth of the adult learners $(20.3 \%)$ immersed this language in communicating with their foreign friends or acquaintances. Most strikingly, beyond three-quarters of the participants $(78.4 \%)$ used the learnt English for speaking practice activities with their friends. It is clear that these adult learners expected to improve their Communication English proficiency. Yet, there were still some learners (29/148, $19.6 \%$ ) unable to access to realistic environment for Communication English use.

Table 6. The adult learners' perceptions of the hindrances on Communication English use

\begin{tabular}{lll}
\hline Hindrances of Communication English Use & F (n) & P (\%) \\
\hline I feel too anxious and scared to speak anything & 81 & 54.7 \\
I am afraid that my inaccurate pronunciation makes listeners not understand & 69 & 46.6 \\
I do not know how to start my speaking & 52 & 35.1 \\
I hesitate to speak as I am afraid that I make incorrect utterances & 95 & 64.2 \\
I do not have sufficient vocabulary for my speaking & 121 & 81.8 \\
\hline
\end{tabular}

As can be seen from Table 6, several factors hindering the adult learners' English speaking performance were ultimately found. To begin with, more than half of the participants $(54.7 \%)$ felt seriously anxious and scared so that they could hardly make a perfect utterance. Likewise, in relation to the learners' psychological aspects, nearly half of the total sample (46.6\%) worried that they pronounced words inaccurately, leading to misunderstandings among interlocutors. Moreover, $35.1 \%$ 
of the total sample often felt embarrassed, did not know how to start their speaking. To another noticeable finding, around two-thirds of the entire response community (64.2\%) hesitated to make utterances as they were afraid of the inaccuracy of what they uttered in English. By the highest percentage, according to four-fifths of the participants (81.8\%), one of the biggest hindrances on their oral performance derived from their limited vocabulary size.

Table 7. The adult learners' overall evaluation on the Communication English class

\begin{tabular}{lll}
\hline Overall Evaluation of Communication English Class & F (n) & P (\%) \\
\hline There exist a lot of suitable speaking activities & 107 & 72.3 \\
The teachers are enthusiastic and have understandable teaching methods & 112 & 75.5 \\
There are many opportunities for English speaking practice throughout the class & 95 & 64.2 \\
The class is little joyful, there are not many opportunities for English speaking practice & 30 & 20.3 \\
The teachers have not still possessed interesting and vivid teaching methods & 18 & 12.2 \\
\hline
\end{tabular}

One of key factors that directly affect the learning performance of Communication English among the adult learners is overall quality of the language center where they are following. From Table 7, the large number of the participants (72.3\%) strongly agreed that the Communication English class at their language center provided them with several suitable speaking activities. Regarding the language teachers, the majority of the informants $(75.5 \%)$ revealed that their language teachers were much enthusiastic and delivered their speaking lessons understandably. Besides, roughly two-thirds of the total sample (64.2\%) applauded that they were exposed to many opportunities for English speaking practice during the class. Nonetheless, there were a few negative aspects of the Communication English class reported by the minority of the respondents; for instance, Communication English class was less joyful and exciting and English speaking activities were not enough for them to practice throughout the class $(20.3 \%)$, as well as some teachers had not still owned interesting and vivid teaching methods $(12.2 \%)$.

Table 8. The adult learners' self-evaluation of the Communication English curriculum

\begin{tabular}{lll}
\hline \multicolumn{1}{c}{ Self-Evaluation of Language Curriculum } & \multicolumn{1}{c}{ F (n) } & P (\%) \\
\hline The language curriculum is vivid and interesting & 119 & 80.4 \\
The language curriculum boring & 29 & 19.6 \\
Total & 148 & 100.0 \\
The language curriculum is suitable to my communicative needs & 108 & 73.0 \\
The language curriculum is not consonant with my communicative needs & 40 & 27.0 \\
Total & 148 & 100.0 \\
The language curriculum is communicative competence-focused & 124 & 83.8 \\
The language curriculum is grammar-focused & 24 & 16.2 \\
Total & 148 & 100.0 \\
\hline
\end{tabular}

Coupled with the overall evaluation (e.g. the teachers, the learning activities), the assessment of the adult learners to the curriculum content of their Communication English was also considered. As Table 8 illustrates, while four-fifths of the participants (80.4\%) assumed that the content of Communication English courses was vivid and interesting, one-fifth (19.6\%) reported that the curriculum at their language center was boring. In addition, nearly three-quarters of the respondents (73.0\%) approved of the suitability of the curriculum content to adult learners' communicative needs; by contrast, one-quarter $(27.0 \%)$ stated that the curriculum content was not in accordance with their communicative needs. Positively, most of the Communication English curricular at the language centers were communicative competence-based, revealed by $83.8 \%$ of the target sample. Only $16.2 \%$ perceived that grammar-focused curriculum still survived at their language schools.

As displayed in Table 9, there are several perks that adult learners could possess when learning Communication English. First, a greater part of the respondents (84.5\%) had high motivation and strong determination before attending the Communication English class. To the most striking finding, nearly all the total sample (87.2\%) identified a clear learning goal for their attendance to Communication English class. Besides, the vast availability of Communication English centers and courses was positively confirmed by more than two-thirds of the total informants (68.2\%). 
Table 9. The adult learners' perceived perks in Communication English learning

\begin{tabular}{lll}
\hline \multicolumn{1}{c}{ Perceived Possible Perks } & F (n) & P (\%) \\
\hline I have high motivation and strong determination & 125 & 84.5 \\
I set up my clear learning objectives & 129 & 87.2 \\
Many Communication English courses are available & 101 & 68.2 \\
I am capable of deploying the Internet for my learning & 83 & 56.1 \\
There exist many opportunities for English speaking practice with foreigners & 22 & 14.9 \\
I have a good foundation of grammar and vocabulary knowledge & 69 & 46.6 \\
I am able to learn autonomously & 92 & 62.2 \\
I know how to apply what I learned into reality & 34 & 23.0 \\
I can establish my own environment for English speaking practice & 28 & 18.9 \\
\hline
\end{tabular}

In addition, many of them unraveled that they had a good self-learning capacity; that is, learner autonomy (62.2\%). Moreover, the learner autonomy of the adult learners was also reflected by their ability to use the Internet for their learning Communication English (56.1\%). What is more, nearly half of the total participants (46.6\%) equipped themselves with a good basis of vocabulary and grammar knowledge. Finally, some other perks belonged to the smaller part of the adult learners; for example, being capable of applying what they learnt into practical (23.0\%), being able to create the environment of English speaking practice environment by themselves (18.9\%). having realistic environment for their English communicative practice with foreigners (14.9\%).

Table 10. The adult learners' perceived perils in Communication English learning

\begin{tabular}{lll}
\multicolumn{1}{c}{ Perceived Existing Perils } & F (n) & P (\%) \\
\hline I have no much time for my learning & 88 & 59.5 \\
I face difficulty in pronouncing words accurately & 62 & 41.9 \\
I have problems with listening comprehension & 104 & 70.3 \\
I do not possess my clear learning goal & 11 & 7.4 \\
I do not have effective learning methods & 82 & 55.4 \\
I lack my self-confidence in my English capacity & 95 & 64.2 \\
There is a shortage of practice environment & 73 & 49.3 \\
I do not possess sufficient knowledge of vocabulary and grammar & 77 & 52.0 \\
I do not still have a good language teacher & 26 & 17.6 \\
\hline
\end{tabular}

Table 10 above illustrates some perils that the adult learners confronted during their learning of Communication English. To begin with, 59.5\% of the respondents did not have much time for their immersion with Communication English. Similarly, based on the revelation of approximately half of the whole sample $(49.3 \%)$, there was a severe lack of realistic environment for them to practice English speaking. In addition, roughly half of the entire sample (55.4\%) did not possess effective learning methods and techniques. Besides, one of the commonly-faced perils in learning Communication English was the adult learners' lack of self-confidence (64.2\%). Table 10 also points out a set of different challenges on the adult learners' speaking performance concerning language input (e.g., vocabulary, grammar, pronunciation, listening comprehension); for example, having trouble in accurate pronunciation $(41.9 \%)$, in listening comprehension $(70.3 \%)$, deficiency of grammar and vocabulary input (52.0\%). Furthermore, $17.6 \%$ of the total sample did not still seek a good language teacher for themselves; and, $7.4 \%$ of this group not still having a clear goal for their learning of Communication English.

As observed from Table 11, by the highest percentage, four-fifths of the participants $(81.1 \%)$ expected the language teachers to supplement extra-curricular activities for their speaking practice. By the second highest percentage, a big portion of the adult informants (70.9\%) looked forward to learning Communication English with foreign teachers more. More than two-thirds of the entire sample $(65.5 \%)$ hoped the language teachers could offer them different amusing learning activities like watching movies, doing role play, jigsaws, game-like activities. Moreover, nearly half of the participants $(45.3 \%)$ expected the language centers to minimize the number of the learners in each class so that the quality of their Communication English class could be improved. Finally, only a very small part of the total sample (9.5\%) attributed the quality of their Communication English class to the regular presence of Vietnamese teachers. 
Table 11. The adult learners' suggested solutions for better Communication English learning

\begin{tabular}{lll}
\hline \multicolumn{1}{c}{ Suggested Solutions } & \multicolumn{1}{c}{ F (n) } & P (\%) \\
\hline Minimize the quantity of learners in each class & 67 & 45.3 \\
Expand time of learning Communication English with foreign teachers & 105 & 70.9 \\
Increase time of learning Communication English with Vietnamese teachers & 14 & 9.5 \\
Supplement extra-curricular activities for speaking practice & 120 & 81.1 \\
Offer different amusing learning activities like watching movies, doing role plays & 97 & 65.5 \\
\hline
\end{tabular}

\subsection{Discussion}

\section{Research Question 1: Adult Learners' Perks and Perils in Communication English learning}

First of all, the quantitative results indicated that all the participants came to the Communication English class due to their specific purpose. In common, these adults wanted to improve their English in terms of fluency and accuracy to serve communicative purposes at work, to meet the qualification requirement at school or workplace, and to seek a better job. According to Cozma (2015), unlike younger learners, the adults always have a reason why they are studying. Thus, the majority of the adult learners had strong inner motivation and established a clear learning goal. As the adult learners had well-defined motive for their learning, they participated in communicative activities actively. Actually, many adult learners used English for various communicative needs outside the class; for example, they practiced Communication English at workplace, at the English language clubs, in chat with foreign friends, in rehearsal with their friends or classmates. Obviously, adult learners, are goaloriented and motivated because when they learn, they want to accomplish specific needs such as to support their study, to be promoted in career, to make more friends or to be good language users (Brockett \& Hiemstra, 2018). Their willingness to learn Communication English does not need to be told or forced to do it.

As for their language centers and teachers, it is indicated the questionnaire results that the Communication English classes at their language centers provided them with several interesting and appropriate learning activities. In addition, they were exposed to many opportunities for English speaking practice during the class. In addition, their language teachers were enthusiastic and taught their speaking lesson in an understandable manner. These perks were perceived from the big part of the participants' positive attitudes. Attitudes, which refer to students' feeling about the language teacher or the language class, influence directly their language learning (Ahmed, 2015). Undoubtedly, the quality of teachers, language centers, and curriculum motivated the adult learners to constantly engage into their class. Furthermore, these good aspects could help the learners outperform their speaking ability.

Coupled with the aforementioned perks, the adult learners also owned some perils in their learning Communication English. First of all, the results from the questionnaire copies showed that most of the adult learners only frequently spent around one hour for each time of their studying Communication English outside the class due to their workload or study mass. According Cozma (2015), adult learners have their multiple responsibilities; the adults generally come to the English classroom with a certain level of fatigue. Additionally, the findings of Baharudin, Murad, and Mat (2012) revealed that most of the adult learners found it very hard to manage their time between family, career and study. As a result, they often sacrificed their resting hour or their pleasure time in order to complete their tasks and finance their self-study. $\mathrm{Wu}, \mathrm{Wu}$ and $\mathrm{Le}$ (2014) pointed out in their study that the most common obstacle to adults' learning is lack of time. Similarly, the questionnaire results also documented that the majority of the adult learners felt unconfident when speaking English. In specific, their low selfconfidence derived from their lack of vocabulary size and grammar amount, their incorrect pronunciation. As a result of this, they became hesitant to speak anything. These findings are in the same lines with those of $\mathrm{Wu}$, et al. (2014) that adults especially find difficulty in obtaining a nativelike accent, thus they partially lose confidence. Furthermore, adults often find it stressful when they are unable to express themselves clearly and correctly in a second language.

Pertaining to the adult learners' views of the language teachers and centers, the questionnaire results unraveled that although some language teachers were sufficiently enthusiastic and easy-going along with a comprehensible instructional path, they did not still innovate their teaching methods. According to some participants, those teachers did not impart the lessons vividly and interestingly. 
Especially, some participants from the data source stated that the curriculum content appeared to be somehow grammar-based. In fact, the teachers tended to focus on imparting much more language knowledge and presenting some speaking tasks. Based upon De Bot (2015); Tsagari \& Banerjee (2016); and Richards (2015), communicating effectively in a foreign language requires the speakers' good understanding of linguistic (accurate knowledge of grammar and vocabulary), sociolinguistic (language in different social contexts), and strategic aspects (ability to use language to achieve communicative goals) of the target language. Indeed, the language teachers seemed to focus much on building up their adult learners' linguistic competence. Therefore, the language teachers should develop these three constructs of communicative competence concurrently. Finally, the results of this study indicated that speaking activities and communicative environment were insufficient for many adult learners to practise. It should be noted that "practice makes perfect"; that is, the more the adult learners practise, the more they become competent English speakers.

\section{Research Question 2: Adult Learners' Suggested Solutions for Communication English learning}

To the first solution group, the questionnaire results displayed that most of the adult learners expected the language teachers to supplement extra-curricular activities for their speaking practice. Based on their suggestion, they believed that these activities could make the class more comfortable and practical, which contributed to their learning success. As mentioned earlier, the adult learners were not provided with sufficient speaking activities and tasks; on the contrary, their language teachers sometimes over-emphasized their linguistic competence. Based on Richards and Rodger (2001) and Diane-Larsen (2019) the integrated components of speaking activities should comprise the aspects of three language models such as structural, functional and interactional use of language. It means that speaking activities used in Communication English classrooms need to focus on three equal components of speaking skills, including accuracy, fluency, and appropriateness. Especially, these extra speaking activities need to be interesting and motivating so the adult learners' instrinsic motivation to Communication English learning increases. In academia, motivation becomes the driving force for learners to be persistent in tedious learning process (Alamer, 2015; Alizadeh, 2016). Thereby, the language teachers should create communicative and fun activities, and select appropriate topics in teaching so that adult learners are motivated to speak English (Heriansyah, 2012).

To the second solution group, nearly half of the participants wanted the language centers to cut down the number of learners in each class so that the quality of their Communication English class could be better. It is inferred that the size of the class and the arrangement of seats detrimentally affect the speaking performance of the adult learners (Bhattacharya, 2017). A conducive and co-operative environment proves to be supportive for learners. It has been observed that adult learners are usually happier and more active in a small class. Kabir (2014) indicates large classes as an inhibiting factor for EFL learners' speaking performance in relation to adult learners who have limited time to show their speaking ability. Teachers pay more attention to each learner, and consequently, learners get more involved in the speaking activities. Concurrently, the more frequent presence of native language teachers in their class was also suggested so that they could be familiarized by the native accents. Being immersed with different English language accents and rhythms can facilitate adult learners' listening comprehension and pronunciation, which eventually leads to a positive change of speaking performance, that is, communicative competence (Nguyen, \& Tran, 2015).

\section{Conclusion}

The adult learners had a plenty of perks when learning Communication English. First of all, almost all the participants came to the Communication English class due to their specific purpose. Secondly, the majority of the adults had strong inner motivation and established a clear learning goal. Thirdly, many adult learners utilized English for various communicative needs outside the classrooms. Fourthly, a large number of the students had positive attitudes towards their language teachers and centers, including: 1) their language center provided them with several appropriate learning activities, 2) their language teachers were enthusiastic and taught their speaking lesson in an understandable manner. In general, motivation, clear goals, and positive attitudes can facilitate these adult learners to acquire Communication English with ease.

Coupled with the aforementioned perks, the adult learners also faced some perils in their learning Communication English. First, most of the adult learners lacked time for Communication English selfstudy outside the class due to their workload or study mass. Secondly, the majority of the adult learners 
felt unconfident when speaking English, which could derive from their immature vocabulary and grammar input. Thirdly, a few adults had negative attitudes towards their language centers and teachers such as 1) some teachers did not deliver the lessons vividly and interestingly, 2) the curriculum content was grammar-based to some extent. Some solutions were ultimately made by the adult learners in this study. For language teachers, most of these adult learners expected their language teachers to furnish appealing extra-curricular activities for their speaking practice. For language centers, many adult learners also longed for these sites to curtail the quantity of learners in each class, to render more modern equipment for them to practice speaking tasks, and to invite native language teachers to their class more frequently.

\section{REFERENCES}

Ahmed, S. (2015). Attitudes towards English language learning among EFL learners at UMSKAL. Journal of Education and Practice, 6(18), 6-16.

Alamer, A. (2015). The role of EFL learners' motivation in mobile language learning. In Comunicación Presentada en el First International Conference on Theory and Practice. Adelaide: Australia.

Alizadeh, M. (2016). The impact of motivation on English language learning. International Journal of Research in English Education, 1(1), 11-15.

Alsayed, M. (2003). Factors that contribute to success in learning English as a foreign language. Damascus University Journal, 19(1-2), 21-44.

Baharudin, S. N. A., \& Murad, M., \& Mat, N. H. A. (2012). Challenges of adult learners: A case study of full time postgraduates students. Procedia - Social and Behavioral Sciences, 90, 772-781. https://doi.org/10.1016/j.sbspro.2013.07.151

Bhattacharya, S. (2017). A study on the factors affecting ESL learners' English speaking skills. International Journal of English Research, 3(4), 31-37.

Brockett, R. G., \& Hiemstra, R. (2018). Self-direction in adult learning: Perspectives on theory, research, and practice. Routledge. https://doi.org/10.4324/9780429457319

Canale, M., \& Swain, M. (1980). Theoretical bases of communicative approaches to second language teaching and testing. Applied Linguistics, 1, 1-47. https://doi.org/10.1093/applin/I.1.1

Cozma, M. (2015). The challenge of teaching English to adult learners in Today's World. Procedia - Social and Behavioral Sciences, 197, 1209-1214. https://doi.org/10.1016/j.sbspro.2015.07.380

Creswell, J. W., \& Hirose, M. (2019). Mixed methods and survey research in family medicine and community health. Family Medicine and Community Health, 7(2). https://doi.org/10.1136/fmch-2018-000086

Crystal, D. (2003). English as a global language. Cambridge, UK: Cambridge University Press. https://doi.org/10.1017/CBO9780511486999

Curle, S. M., \& Derakhshan, A. (2021). Trends in using questionnaires for EMI research: Suggestions for future improvements. In Research Methods in English Medium Instruction (pp. 32-45). Routledge. https://doi.org/10.4324/9781003025115-3

Dao, T. T. H. (2017). Task-based language teaching: An insight into teacher practice. International Journal of Education Culture and Society, 2(4), 126-131. https://doi.org/10.11648/j.ijecs.20170204.14

Darkenwald, G. G., \& Merriam S. B. (1982). Adult education: Foundations of practice. N.Y.: Harper Collins.

De Bot, K. (2015). A history of applied linguistics: From 1980 to the present. London: Routledge. https://doi.org/10.4324/9781315743769

Diane, L. (2019). Techniques and principles in language teaching. Oxford: Oxford University Press.

Dörnyei, Z. \& Taguchi, T. (2010). Questionnaires in second language research: Construction, administration, and processing. 2nd Edition. Oxfordshire, UK: Routledge. https://doi.org/10.4324/9780203864739

Enever, J. (2018). Policy and politics in global primary English. Oxford University Press.Heriansyah, H. (2012). Speaking problems faced by the English Department students of Syiah Kuala University. Lingua Didaktika, 6(1), 37-44. https://doi.org/10.24036/ld.v6i1.7398

Heriansyah, H. (2012). Speaking problems faced by the English Department students of Syiah Kuala University. Lingua Didaktika, 6(1), 37-44. https://doi.org/10.24036/ld.v6i1.7398 
Hosni, S. (2014) Speaking difficulties encountered by young EFL learners. International Journal on Studies in English Language and Literature, 2(6), 22-30.

Iwaniec, J. (2019). Questionnaires: Implications for effective implementation. In The Routledge handbook of research methods in applied linguistics (pp. 324-335). London: Routledge. https://doi.org/10.4324/9780367824471-28

Juhana (2012). Psychological factors that hinder students from speaking in English class (A case study in a senior high school in South Tangerang, Banten, Indonesia). Journal of Education and Practice, 3(12), 100-110.

Kabir, U. S. (2014). Challenges of speaking in Bangladeshi classrooms (Unpublished Master's Thesis). Bangladesh: Bangladesh University.

Kirkpatrick, A. (2007). World Englishes: Implications for international communication and English language teaching. Cambridge: Cambridge University Press.

Kuklewicz, A., \& King, J. (2018). "It's never too late": A narrative inquiry of older Polish adults' English language learning experiences. TESL-EJ, 22(3), 1-22.

Larsen-Freeman, D. (2018). Looking ahead: Future directions in, and future research into, second language acquisition. Foreign Language Annals, 51(1), 55-72. https://doi.org/10.1111/flan.12314

Lavrysh, Y. and Lytovchenko, I. (2019). The case of education for sustainable development approaches implementation at English language classes at the technical university in Ukraine. Pedagogy, 91(5), 736 $-749$.

Leong, L-M. \& Ahmadi, S. M. (2017). An analysis of factors influencing learners' English Speaking Skill. International Journal of Research in Language Education, 34-41. https://doi.org/10.18869/acadpub.ijree.2.1.34

Lytovchenko, I., Ogienko, O., Sbruieva, A., and Sotska, H. (2018). Teaching English for specific purposes to adult learners at university: methods that work. Advanced Education, 10, 69 - 75. https://doi.org/10.20535/2410-8286.149741

Madkur, A. (2018). The non-English major lecturers speak English: The barriers encountered by adult learners. Journal on English as a Foreign Language, 8(1), 39-56. https://doi.org/10.23971/jefl.v8i1.584

Mazouzi, S. (2013). Analysis of Some Factors Affecting Learners' Oral Performance. A Case Study: 3rd Year Pupils of Menaa's Middle Schools (Unpublished master's thesis). People's Democratic Republic of Algeria: University of Biskra

Merriam, S. B. (2017). Adult learning theory: Evolution and future directions. PAACE Journal of Lifelong Learning, 26, 21-37.

Nguyen. H. T. \& Tran, N. M. (2015). Factors affecting students' speaking performance at Le Thanh Hien high school. Asian Journal of Educational Research, 3(2), 8-23.

Nunan, D. (1991). Language teaching methodology. A textbook for teachers. New York: Prentice Hall International, Ltd.

Patten, M. (2016). Questionnaire research: A practical guide. London: Routledge. https://doi.org/10.4324/9781315265858

Pham, V. P. H., Than, T. L., \& Truong, M. H. (2020). Vietnamese high school students' appraisal of speaking problems and influential factors. International Journal of English Language Studies, 2(3), 33-44. https://doi.org/10.32996/ijels.2020.2.3.4

Richards, J. C. (2015). Key issues in language teaching. Cambridge: Cambridge University Press

Richards, J. C., \& Rodgers, T. (2001). Approaches and methods in language teaching (2nd Ed.). NY: Cambridge University Press. https://doi.org/10.1017/CBO9780511667305

Singleton, D., \& Záborská, D. (2020). Adults learning additional languages in their later years: The pain, the profit, and the pleasure. Journal of Multilingual Theories and Practices, 1(1), 112-124. https://doi.org/10.1558/jmtp.15361

Trueman, M. \& Hartley, J. (1996). A Comparison between the time-management skills and academic performance of mature and traditional-entry university students. Higher Education, 32(2), 199-215. https://doi.org/10.1007/BF00138396

Tsagari, D., \& Banerjee, J. (2016). 1. The handbook of second language assessment (pp. 1-10). De Gruyter Mouton. https://doi.org/10.1515/9781614513827-029 
Ur, P. (2013). A course in English language teaching. Cambridge: Cambridge University Press. https://doi.org/10.1017/9781009024518

Wu, R., Wu. R., \& Le, V. T. (2014). Challenges of adults in learning English as a second language: Focus on adult education in China. Journal of Language Teaching and Research, 5(5), 1132-1138. https://doi.org/10.4304/jltr.5.5.1132-1138

Xolmurodova, O. (2021). Increasing basic language skills of young learners in English lessons. Журнал иностранных языков и лингвистики, 2(3).

Yaseen, N. B. (2018). Factors negatively affecting EFL students' speaking skills at Jordanian private schools (Unpublished master's thesis). Jordan: Middle East University. 